\title{
Reformation of the Administration of Village Government in Indonesia Based on Law Number 6 of 2014 on Villages (Comparing Normative and Empirical Facts on Villagers Participation)
}

\author{
Rodiyah \\ Faculty of Law, Universitas Negeri Semarang (UNNES), Indonesia \\ Email: rodiyah@mail.unnes.ac.id
}

\begin{abstract}
The Implementation of Village Government in Indonesia is based on Law Number 6 of 2014 on Village (Village Act). This law mandates ten percent of the State Revenues and Expenditure Budget (ABPN) channeled to the Village. The funds are considered important and necessary as a form of central government support in rural development and development in Indonesia. However, problems in village administration and budget management are among the challenges facing today. The number of cases of village budget fraud has caused the implementation of Village Government not yet optimal. Infrastructure and human resources are also considered not enough to understand the pattern of village fund management, resulting in imbalance, concerns, and even fear in managing village funds. In fact, the budget is expected to be used to achieve the goal of justice in the village fair.
\end{abstract}

Keywords - Village Government, Village Fund, Village Government Administration, Reformation

\section{INTRODUCTION}

The Government on January 15, 2014 has established Law no. 6 Year 2014 on the Village. The consideration of the law indicates that the Village has the right of origin and the traditional right to organize and manage the interests of the local community and play a role in realizing the ideals of independence under the 1945 Constitution of the State of the Republic of Indonesia. This Act among others regulates the Status and Type of Village; Village Arrangement; Village Authority; Implementation of Village Government; Rights and Duties of Villages and Villagers; Village Finance and Village Assets; and Village Development and Rural Area Development. Even villages domiciled in the Regency / City area, consisting of Village and Desa Adat (customary village) in accordance with the prevailing mention in the local area. Government, Provincial Government and Regency / Municipal Government, pursuant to Article 7 of this law, the village can undertake the arrangement of the village, which includes: Formation; Removal; Merger; Status changes; and Village setting.

The authority of the village includes the authority in the field of governance of the Village, the implementation of village development, the village community development, and the empowerment of the village community based on the community's initiative, the right of origin and village customs. Article 23 of this law stipulates that Village Governance shall be administered by the Village Government, namely the Village Head or called by other names assisted by the village apparatus or called by other names. The village head is responsible for organizing village governance, village community development, and empowerment of rural communities. In performing its duties, according to Article 26, paragraph 3 (c) and 3 (d), the
Village Head shall be entitled to receive a fixed monthly income, other allowances and legal receipts, as well as health insurance, and obtain legal protection for the implemented policy.

The normative fact of Law No. 6 of 2014 mandated $10 \%$ of the State Budget (APBN) to be channeled to the Village. Then empirical facts follow with the logic will be a challenge to the process of management and politics of seizure of the position of village head, the quality of human resources in the management of village administration and the quality of BPD in the mechanism of making Revenue and Expenditure Budget Village (APBDes). With a fund of $10 \%$ of the national budget (APBN) of 59.2 trillion for 73 thousand villages in Indonesia, not to mention the $10 \%$ regulation of $\mathrm{APBD}$, it is predicted to make village afraid simultaneously stuttered in managing the village administration as well as triggering potential village actors to compete for office villages including unhealthy village office positions. Rodiyah's research (2013) indicates that the problem of village management relies on the management of village management which is deprived of the true value of local wisdom if local value is used in the administration of village government will strengthen the achievement of justice in village fairness goal. The fundamental changes of the empirical, reality and normative governance in the village administration after the Village Act enacted become the focus of this paper.

This condition indicates that the village should be developed in accordance with the perspective of Village Act. The ideal model for managing village governance to realize welfare based on the value of local wisdom, this focus has a common thread by developing the results of Rodiyah (2011) effective invitations of RegMap and Regulatory Impact Assessment (IRR), which were tested by Rodiyah (2012) 
implementation of the IRR model. This study examines, finding the ideal model of management of village governance perspective Village Act.

Weak community participation (voice, access and control) is another side of weak democratic practice at the village level. Until now, the elite of Kedungkelor Village did not have a sufficient understanding of participation. For the village head, participation is a form of community support for village government development policies. The village government mobilizes community-based mutual assistance and assistance (both of which are included as revenue sources for APBDes) to support rural development. The people concerned need to be informed, so the relationship between government and community becomes closer, friendly as partners, mutually supportive, and efficient. This condition is the background of the empirical, sociological and normative needs of research model of governance of village governance perspective Act No. 6 of 2014 .

\section{RESEARCH METHOD}

The focus of this research is on the implementation of village government perspective Village Act On the research problem (1) How to Model Village Government Implementation Perspective of Village Act, (2) How is normative relationship of Village Act with Sociological Empirical Facts of Village Community Participation in Realizing a Village that is advanced, independent, and prosperous without having lost identity ? Objective of research to find Model of Village Government Implementation Perspective of Village Act; and describes the normative relationship of Village Act with Sociological Empirical Facts of Village Community Participation in Realizing a Village that is advanced, independent, and prosperous without losing identity.

The concept and theory used is the legal concept of Village Act, Regulations Number 43 of 2014, the concept of good governance, the theory of the Working of the Law of Chambliss and Seidman, the cybernetic theory of Talcott Parsons which will show about the reasons for the action of the domain of the formation of village regulations; the draft regulation of the IRR model, the concept of political configuration Moh. Mahfud MD, Legal Communication theory Hurgen Habermas; as well as legal system Lawrence M Freidman.

The research process uses a paradigm of constructivism, a qualitative-hermeunitic approach with socio-legal research. Data analysis using Chambliss and Seidman's Theoretical Working Thread in the interaction analysis of constructivism model on $\mathrm{R} \& \mathrm{D}$ analysis techniques. The study was conducted at the northern coastal village institution of Tegal regency, in Central Java.

\section{RESULT AND DISCUSSION}

\section{A. Model of Village Government Implementation Perspective Law No. 6 of 2014 about Villages}

The results of research on one of the research villages of Kedungkelor Village, Warurejo Sub-District, Tegal Regency, showed that in improving the quality of public service, they have made internal improvements in improving the capacity of Village Devices by involving them in training, disseminating the implementation of Law no. 6 Year 2014 conducted by the Government of Tegal Regency. As a result village apparatus better understand the meaning, direction and purpose of the Act. It is also done in BPD by participating in the same activity. This is intended to provide a common perception in implementing the village law. This condition is done to synergize between the village (village head and village apparatus) and the BPD is able to become a pillar of village empowerment to create an independent village with a strong identity.

Some activities that have been done include the preparation of APBDes in a transparent, effective, efficient and accountable mechanism in accordance with the law that rests on the work of the law Chambliss and Seidman. In addition gradually the village government has also strived to uphold the principles of good local governance, so that all activities can be implemented according to the expectations of various interested parties. Thus the village government with support from BPD can be seen as a significant internal strength factor for governance.

Domain implementation of the Village Head as the highest organizer who has the function of motivator, mobilizer and initiator at the same time carried out the villagers mandate through the Village Rules that have been agreed in the Village Deliberation. Therefore the role of the Village Head is important to have great leadership at the village leadership level. Shared village leadership is an idealized leadership model in Village to mobilize all elements of village potential to participate in rural development. This is where the meaning of community participation is very important in the implementation of village development.

At the domain level of the supervisor, the role of BPD (although not explicit as the supervisor of the implementation of village governance) but implicitly is to conduct supervisory tasks within the village deliberation room to determine the development mechanism undertaken by the Village Head.

The context of the formulation of village regulations that is carried out by the mechanism of legal work in the above ritual is the establishment of an ideal village regulation is by IRR mechanism (integrative RIA with RegMap). The Integrative Model Reg Map-RIA is a model constructed using the meaning of the RegMap substance (mapping of existing legislation through synchronization and harmonization of existing legislation vertically and horizontally so as to produce the regulatory priorities contained in the village legislation program (prolegdes) and further the regulatory priorities should be immediately reRIA-that is, after going through RegMAP, the RIA implementation will be more effective by using six stages, such as problem formulation, objective identification, action alternatives, cost and benefit analysis, selection of action and implementation strategy. These six steps must exist in the public consultation corridor embodied in the formation of Academic Manuscripts Each stage should be based on the formal and material aspects of democracy. 
This formation model is in accordance with Government Regulation No. 43 Year 2014 so as to realize the implementation of the Village based on the principle of good governance and in line with the principle of village arrangement as mandated by Law Number 6 Year 2014 on the Village, among others legal certainty, orderly governance, public order, openness, professionalism, accountability, effectiveness and efficiency, local wisdom, diversity and participation. In carrying out the development of the village, preferably the value of togetherness, kinship, and mutual cooperation in order to realize the Village of Advanced, Independent, and Prosperous without Losing Your Own Character.

B. Normative Relation of Law No. 6 of 2014 with Sociological Empirical Facts Village Community Participation in Realizing a Developed, Independent, and Prosperous Village

The results of normative empirical research showed that the ratification of Law no. 6 Year 2014 on the Village becomes an important milestone for village governance, because the Village Act shows a real commitment as well as the existence of political will as Good Will of the State to empower the village and improve the welfare of all the tools of the village as well as the potential vulnerability that follows. Commitment and political will are shown in several ways, such as:

1. There is budget allocation from APBN for village development. This policy is set forth in Article 71 that each village will get an allocation of funds from the state budget amounting to ten percent of balancing funds received by the district / city in the APBD after deducting the special allocation fund $(D A K)$. The value is adjusted to the village's geographic conditions, population and poverty rate. So far, the original income of the village is derived from the original income of the village consisting of: business results, yields, self-help and participation, gotong royong (mutual assistance), and other village original revenues, part of the local taxes and retributions of districts / municipalities, is part of the balance funds received by the district / city, financial assistance from the Provincial Revenue and Expenditure Budgets and the Regional Revenue and Expenditure Budgets, grants and non-binding contributions from third parties; and other legitimate village revenues.

2. The existence of revenues sourced from the APBN budget allocation is certainly a positive new policy and an important point for the development and empowerment of village communities. Villages face many problems, including poverty, poor health status, low education level, high unemployment rate, low capacity of village administration, natural environment damage, infrastructure damage etc. With significant additional village revenues, these problems will continue to be addressed and addressed in accordance with village priorities and authorities. Moreover, planning, allocation, implementation and accountability of the use of funds implemented by the village itself, of course this is a real action for community empowerment. However, the consequences of the delivery and delegation of financial management must be accompanied by capacity building of managers through training, fostering the administration of village finances along with continuous monitoring so that funds can be managed accountably, transparently, on time, on quality, proper administration and on target.

3. There are fixed income, allowances and health care for village head and village apparatus. The village head and village apparatus are essentially state administrators at the village level. Its existence is very strategic in the system of state administration, because the village is the estuary of all government programs and development, besides the village is the base of data as the source of information and national and regional policy, so for the smoothness and success of the programs of government and development, village strengthened both from the institutional side, capacity apparatus and authority. The most significant effect on the improvement of the performance of the village apparatus is the improvement of welfare.

4. From the aspect of authority, there is an additional authority of the village in addition to the authority based on the right of origin as recognized and respected by the state also to the discretion in determining local authority and decision-making locally for the benefit of the village community. The local authority of the village is the authority to organize and manage the interests of villagers who have been run by the village or are able and effectively carried out by the villages, or that arise because of village development and village community initiative, such as boat moorings, village markets, public baths, irrigation, environmental sanitation, integrated service post, art studio and study, as well as village library, rembung and road of village.

5. The implications of the village may be to use the financial resources originating from the state and local governments to develop all existing, emerging, and some other authorities that may be the assignment of supradesa. The law also determines that the general sources of public finance come from APBN, APBD, $\mathrm{PAD}$ and other legitimate sources. In fact every village gets as much as $10 \%$ of the total APBN, plus ADD of $10 \%$ of Taxes / Levies / DAU / DBH, plus Original Village Income and other legitimate contributions, and each village of 72,944 villages in April 2015 will earn 1.4 Billion.

6. Implementation of village governance so far describes the low support of facilities and infrastructure so that the service in the village is not maximal. The village office is even generally not working except at certain times. The research results show that village hall is still limited as a deliberation room which is done monthly or bimonthly. So not as an interactive communication media between the community and village head, village officials and BPD.

7. Other facts indicate that the posture of the village government organization, the boundaries of village government consists of village head and village apparatus alone without BPD position. The limitations 
are different when compared to the regulation in PP No. 72 of 2005, where village governance consists of village heads and BPD. The separation of the village head's position and the tools from the BPD enabled the village administration to be more effective in implementing village autonomy than the obligations of supradesa. Experience shows that the collectivity of village heads and BPDs as an element of village governance is difficult because both institutions are not always aligned in setting and implementing policies. The separation of the position of BPD allows the village government to more freely organize and manage their own households without strict supervision of BPD which has been relatively difficult to live together with the village government. BPDs at least represent democratically elected societies to discuss a policy before being implemented by the village government. Village policy starts from the planning, implementation and evaluation stage. Village planning is a medium-term plan outlined in the form of annual development planning.
8. The context of the development framework, the village requires active community participation. Opportunities for the development of democratic village autonomy appear to be wide open where the public is entitled to information, monitoring and reporting all activities that are considered to be less transparent to village governments and BPDs. This kind of process is a form of learning of democratic participation through the planning cycle, implementation and evaluation of village development. Thus created a real bottom-up mechanism, not the engineering of village development deliberations as it has been so far. It supports the creation of a more transparent government process within the framework of good governance. Moreover, the opportunity for autonomy development allows the village to expand its development through cooperation strategies with other mutually beneficial villages. others:

The results of the study also show that there are obstacles in Kedungkelor Village in implementing the Act, among

Table 1. The Implementation of Village Act in Kedungkelor Village

\begin{tabular}{cl}
\hline No & Obstacles \\
\hline 1 & $\begin{array}{l}\text { Lack of effectiveness and efficiency in the } \\
\text { administration of village government }\end{array}$ \\
2 & $\begin{array}{l}\text { Lack of public role in the administration of } \\
\text { village government }\end{array}$
\end{tabular}
village government

3 Lack of infrastructure facilities for the implementation of village government

4 Not optimal the implementation of the Village in making APBDes

5 The occurrence of a split due to the impact of village head elections in 2013. Dusun that candidates do not win proposed separation and become a new village, even the obvious is the demo in every activity of village development activities. For example, the normalization of Kalirambut River which is the basic needs of the community in the demo so that the development stalled

\section{Source: Author's Result Research Data}

Dahrendorf (1959: 208) builds the theory of the relationship between community conflict and change. Dahrendorf says that all creativity, innovation and
Solutions

1. Improving the performance of village government;

2. Cooperate with the government to provide guidance and socialization;

3. Include community groups at festivals / performances / cultural activities at all levels

1. Cooperate with BPD to accommodate community aspirations and proposals;

2. Establish village discussion forums (musyawarah);

3. Participation in coaching / training / socialization / other events at all levels

1. Conducting cooperation with related institutions / agencies to hold goods in the village government

2. Maintenance and improvement of quality and facilities of facilities and infrastructure of existing activities

1. In cooperation with relevant institutions / agencies in the making of APBDes;

2. Include the community in training / training / dissemination at Provincial level;

3. 3. In cooperation with local government to organize socialization and technical preparation of APBDes

1. BPD does the approach by cooperating with the village apparatus and the Warurejo Sector Police to negotiate good awareness and cooperation.

2. Deliberation village by bringing all the figures in society and the parties opposed should use persuasive approach.

3. Until now, the deliberation and lobbying of the opposing parties to find a solution. development in the lives of individuals, groups and societies are caused by conflicts between groups and groups, between individuals and individuals and between 
emotions and emotions within the individual. In this concept social conflict has a structural source, namely the power relations prevailing within the organizational structure. The core of Dahrendorf's thought is as follows.

1. Every society in all things is subject to process of change taking place elsewhere.

2. Every society in all matters concerns non-conformities and conflicts, social conflicts are everywhere.

3. Every element of society contributes to its divisions and changes

4. Every society is based on the use of violence by members of its members against other members.

This means that class conflict causes structural changes and spreads so it happens everywhere. In the context of its relationship with the process of governance of the village administration shows the number of conflicts in the process. Among other conflicts of interest between classes within the community, individual conflicts with village heads, village governance-based conflict conflicts based on people's ability, for all, with gender equality, financing conflicts, conflicts of employee structural appointments. These conflicts require management and wisdom based on the interests of the people of the people's villages so that the objectives of village governance are realized in a just and prosperous way.

Based on the theoretical analysis of the theories of Rossi and Freeman that the impact assessment is intended to estimate whether intervention produces the effects of an intervention the impact analysis will begin with the identification of the problem to see the problems, compare the benefits, and analyze the effects of the previous policy with qualitative and normative approaches using performance measures to assess whether goals and targets have been met. The policy effects of the analysis of the theories of Rossi and Freedman are further grown by analysis of the legal system theory of Friedman (1975: 1415) which includes the structure of law, the substance of law and the culture of law.

\section{Legal Structure Aspect in the Implementation of} Village Government.

a. The weakness of vertical and horizontal synchronization due to dependence on the procedure and to the party assigned, not oriented to performance oriented.

b. Too many things need to be integrated between districts and villages, and because of the ineffectiveness of the village Musrebang as a means of synchronization.

c. The lack of community institutions to improve the role of the community in the implementation of village governance.

2. Legal Substance Aspect in the Implementation of Village Government

a. The system of village governance augmentation with district-level planning that will be regulated in local regulations needs to be adjusted more closely to ensure the systematic and harmonious development of all areas of the village, and the proposed changes do not deviate from what will be the village regulations. b. Weak technical planning is integrated into sectors that support the implementation of village governance. Sector integrity is not necessarily achieved by the preparation of a medium-term plan with a chapter for each sector as is customary in the region. Each sector plan needs to be prepared and refined according to need, and the sector plan designer needs to assess integration needs with other sectors, and take his own initiative to prepare the integration by learning all the aspects that need to be integrated into rural development.

c. Weak supervision of the level of quality of service feasibility, effectiveness and efficiency of village administration services.

d. Not yet accommodated approaches in the field of sustainable village development and environmentally sound village.

3. Legal Culture Aspect in the Implementation of Village Government

a. Lack of understanding and awareness of the urgency of village regulations in the administration of the village administration due to the lack of socialization efforts of the village government regarding the rules on the administration of village government.

b. The low level of professionalism of planners (Village Heads, Village Officials and BPDs and communities) to learn all the aspects that need to be integrated, related to the general policy and priorities of village governance that are balanced with adequate preparation.

c. Ineffective involvement of the community actively in the planning process and priority setting of village administration.

d. Potential corruption due to weak supervision and lack of financial administration in the village exacerbated by the amount of money flowing into the village.

\section{CONCLUSION}

Model of reform of village governance perspective of Law no. 6 Year 2014 is an organizing mechanism based on legal work based on domains of village regulators by BPD and Village Heads, Domain Implementers by Village Heads and optimizing the participation of villagers, the domain of supervision is on all components of society from the start of community leaders, religious leaders, youth leaders, village promoters, NGOs, village professors, and even BPD. This model will work effectively starting with the establishment of village regulations that use the IRR model based on community participation that reinforces the village identity on the local value wisdom. There is a relation between the normative meaning of Law no. 6 Year 2014 that must be run with the potential that is generated empirically. Therefore the condition of this fact should be examined through appropriate analysis of constraints, solutions and predictions through the impact analysis by developing the 
concept of legal system (structure, substance and culture of village administration.

The recommendation is that this model is recommended to be implemented and developed adaptively with the public appropriateness of governance of the village administration. The ever-present linearity is often inevitable the emergence of the negative potential of Law No. 6 of 2014 then the village is recommended to be able to make a strategic and progressive prediction in carrying out village management. The concrete is: create technical rules within the scope of legal work on the Technical Policy: the relationship of authority between the village government and the BPD, sub-district and local government; clear control mechanisms to prevent increased opportunities for village corruption; village establishment, village division (pemekaran), village merging; local authorities other than authority based on origin, and authorities conjugated by local, provincial and central government.

\section{REFERENCES}

[1] Hubermas, Jurgen , 2001, Between Fact and Norm, Constribution to Discourse Theory of Law and Democrasy (alih bahasa : William Rehg), Massachusetts, The MIPR Press.

[2] Harold J. Berman, Law and Revolution: The Formation of the Western Legal Tradition (Cambridge: Harvard University Press, 1983).

[3] E. Sumaryono,1999. Hermeneutik, Sebuah Metode Filsafat, Edisi Revisi, Penerbit Kanisius, Yogyakarta .

[4] Friedman, L.M, 1969. Legal Culture and Social Development, Law and Society Review: The Journal Of The Law and Society Association

[5] Jimly Asshiddiqie dan Muchamad Ali Safa'at2006. Teori Hans Kelsen Tentang Hukum, Jakarta : Konstitusi Press.

[6] George Ritzer 1975. Sociology: a Multiple Paradigm Science, Boston Allyn and Bocon.

[7] Khun, Thomas. 1962. The Structure of Scientific Revolution, 2nd ed. 1970. Chicago University Press.

[8] Mahfud MD, 1993,"'Perkembangan Politik : Studi tentang Pengaruh Konfigurasi Politik terhadap Produk Hukum di Indonesia" (Disertasi Doktor), Yogyakarta: Universitas Gadjah Mada.

[9] Philip Nonet dan Philip Selznick, Hukum Responsif, Pilihan Masa Depan, Huma, 2003, hal 26. Buku ini judul aslinya adalah "Law \& Society in Transition : Toward Reponsive Law.

[10] Roberto M. Unger , 1999, Gerakan Studi Hukum Kritis, Lembaga Studi dan Advokasi Masyarakat (ELSAM), Jakarta.

[11] Robert B. Seidman \& William J. Chambles, Law, Order, and Power, Printed in United States of America, Pubhlised Stimulant Costly in Canada Library of Congress Catalog Card No. 78-111948.

[12] Satjipto, Raharjo. Harian Kompas dengan judul "Indonesia Butuhkan Penegakan Hukum Progresif", Kompas, 15 Juni 2002

[13] Satjipto, Raharjo, "Hukum Progresif (Penjelajahan Suatu Gagasan)", Makalah disampaikan pada acara Jumpa Alumni Program Doktor Ilmu Hukum Undip Semarang, tanggal 4 September 2004.

[14] Rodiyah. (2017). "The Policy of Conservation for Justice Values on Law School Curriculum on College Incorporated of UNNES (The Justice Value Based Policy of University's Tridharma", International Journal of Economics and Law, IJBEL Vol. 12 Issue 4, April, E-ISSN: 2289-1552, pp.89-123

[15] Rodiyah. (2016). Aspek Demokrasi dalam Pembetukan Peraturan Perundang-Undangan, BPFH UNNES: Semarang.

[16] Rodiyah. (2009). "Model Strategi Kebijakan Otonomi Daerah dalam Percepatan Pengarusutamaan Gender Bidang Pendidikan di Jawa Tengah", Project Report, DP2M DIKTI, Jakarta.

[17] Rodiyah. "Aspect Democracy in the Formation of Regional Regulation (Case Study the Formation of Regional Regulation about Education in Perspective Socio-Legal)", International Journal of Business, Economics, and Law, IJBEL Vol. 2 Issue 3, June 2013, ISSN: 2289-1552, pp. 43-58

[18] Rodiyah. "Aspek Demokrasi Pembentukan Peraturan Daerah dalam Perspektif Socio-Legal", Jurnal Masalah-Masalah Hukum, Vol. 41 No. 1, January 2012, ISSN: 2086-2695, pp. 53-76

[19] Talcott Parsons (Harry C. Bredemeier, "Law as an Integrative Mechanism", dalam William M. Evan (ed.), Law and Sociology. New York: The Free Press of Gloencoe, 1962.

[20] Undang-Undang No. 32 Tahun 2004 tentang Pemerintah Daerah

[21] Undang-Undang No. 6 Tahun 2014 tentang Desa

[22] Peraturan Pemerintah No. 43 Tahun 2014 tentang Pelaksanaan UU No. 6 Tahun 2014 